INTENSIF, Vol.3 No.1 February 2019

ISSN: 2580-409X (Print) / 2549-6824 (Online)

Website: http://ojs.unpkediri.ac.id/index.php/intensif

\title{
Si-Bidan: Sistem Informasi Kesehatan Ibu dan Anak
} Si-Bidan: Maternal and Child Health Information System

\author{
${ }^{1}$ Dedy Hidayat Kusuma, ${ }^{2}$ Moh. Nur Shodiq, ${ }^{3}$ Dianni Yusuf, ${ }^{4}$ Lailatus Saadah \\ 1,2,3,4 Teknik Informatika, Politeknik Negeri Banyuwangi \\ ${ }_{1,2,3,4}$ Banyuwangi, Indonesia \\ E-mail: 1dedy@poliwangi.ac.id, ${ }^{2}$ noer.shodiq@poliwangi.ac.id, \\ 32dianniyusuf@poliwangi.ac.id, ${ }^{4}$ lailatulsaadah04@gmail.com
}

\begin{abstract}
Abstrak-Bidan merupakan salah satu tenaga kesehatan yang memberikan layanan kesehatan ibu dan anak (KIA) dan keluarga berencana (KB). Saat ini sebagian besar pencatatan layanan bidan masih dikelola secara konvensional yakni dengan pencatatan manual. Hal tersebut kurang efektif dan efisien yang menyebabkan beban waktu kerja bertambah, proses temu kembali informasi yang cukup lama dan resiko hilangnya data-data penting kemungkinan akan sering terjadi. Disisi lain, pasien ibu diharuskan mendatangi bidan secara langsung apabila ingin mengetahui informasi perkembangan kehamilan dan anak balitanya . Berdasarkan fakta tersebut maka dibangun sistem informasi KIA yang dapat diakses oleh bidan dan orang tua. Sistem informasi yang dikembangkan terdiri dari dua aplikasi yang terintegrasi yaitu aplikasi berbasis web untuk bidan dan aplikasi mobile bagi orang tua. Aplikasi web memfasilitasi bidan untuk melakukan pencatatan transaksi, pembuatan laporan, dan penyampaian informasi kepada pasien. Sedangkan aplikasi mobile memudahkan orang tua untuk memantau perkembangan kesehatan ibu dan anak serta informasi lain yang diberikan oleh bidan. Sistem dikembangkan dengan menggunakan model pengembangan perangkat lunak water-fall. Hasil pengujian menggunakan metode black-box test menunjukkan bahwa sistem KIA yang dibangun telah mampu memenuhi kebutuhan fungsional pengguna.
\end{abstract}

Kata Kunci-sistem informasi, web, mobile, bidan, kesehatan ibu dan anak

Abstract - Midwives are one of the health workers who provide child and maternal health (CMH) services and family planning. At present, most of the recording of midwife services is still managed conventionally by manual book keeping. It is less effective and efficient which causes the workload to increase, the information retrieval process is quite long and the risk of missing important data is likely to occur frequently. On the other hand, maternal patients are required to visit the midwife directly if they want to know the information on the progress of the pregnancy and their child. Based on these facts, a CMH information system was built that was accessible to midwives and parents. The information system developed consists of two integrated applications, namely web-based applications for midwives and mobile applications for parents. The web application facilitates midwives to record transactions, make reports, and deliver information to patients. While the mobile application makes it easier for parents to monitor the development of maternal and child health and other information provided by midwives. The system was developed using the water-fall software development model. The test results using the blackbox test method indicate that the CMH system has been able to meet the user's functional requirements.

Keywords-information system, midwives, web, mobile, child and maternal health 
INTENSIF, Vol.3 No.1 February 2019

ISSN: 2580-409X (Print) / 2549-6824 (Online)

Website: http://ojs.unpkediri.ac.id/index.php/intensif

\section{PENDAHULUAN}

Sektor kesehatan merupakan salah satu sektor pembangunan yang sedang mendapat perhatian besar dari pemerintah yang merupakan salah satu sektor pembangunan yang sangat potensial untuk dapat diintegrasikan dengan kehadiran teknologi informasi [1]. Salah satunya yaitu Program Kesehatan Ibu dan Anak (KIA) di bidan desa yang merupakan salah satu program yang memberikan pelayanan kesehatan yang terlibat langsung dengan masyarakat. Upaya kesehatan ibu dan anak adalah upaya dibidang kesehatan yang menyangkut pelayanan dan pemeliharaan ibu hamil, ibu bersalin, ibu meneteki, bayi dan anak balita serta anak prasekolah [2]. Dengan adanya program KIA yang diselenggarakan di wilayah desa diharapkan dapat meningkatkan kesadaran, kemauan, dan kemampuan hidup bagi ibu dan anak yang bertempat tinggal di wilayah desa. Untuk meningkatkan kinerja program kesehatan diperlukan ketersediaan informasi yang cepat dan akurat karena penting dalam mendukung upaya menciptakan kualitas pelayanan yang baik [3].

Kegiatan pelayanan KIA di bidan desa saat ini meliputi proses pendaftaran pasien, pencatatan hasil pemeriksaan, pencatatan pemberian obat atau vitamin anak, dan laporan harian maupun bulanan masih menggunakan pencatatan dalam buku kohort yang merupakan pembukuan hasil laporan kegiatan pemeriksaan dengan volume transaksi yang tinggi setiap harinya. Faktanya ketika pasien datang untuk melakukan proses pemeriksaan kesehatan atau yang lain petugas masih harus mencari data pasien yang tercatatat dalam buku sehingga membutuhkan waktu yang lama. Selain itu juga sering terjadi kesulitan dan keterlambatan dalam membuat rekapitulasi data pasien setiap harinya ataupun laporan bulanan karena data disarikan dari buku kunjungan dan lembaran dokumen lainnya. Hal tersebut kurang efektif dan efisien sehingga menyebabkan beban waktu kerja bertambah, penyajian informasi yang cukup lama dan resiko hilangnya data-data penting kemungkinan akan sering terjadi [4]. Disisi lain untuk mendapatkan informasi yang berhubungan dengan KIA, pasien harus datang dan menanyakan secara langsung kepada bidan desa. Waktu yang dibutuhkan pasien juga bertambah seiring dengan waktu yang dibutuhkan bidan untuk temu kembali informasi pasien. Kepemilikan ponsel pintar oleh sebagian besar ibu sebenarnya juga membuka peluang dalam penyampaian informasi KIA yang lebih cepat.

Beberapa aplikasi berbasis web untuk mendukung program KIA bagi bidan telah banyak dikembangkan namun belum dilengkapi dengan aplikasi mobile seperti sistem pelaporan KIA [5], manajemen informasi KIA [[6], pelayanan KIA [7], manajemen posyandu [8], dan pelaporan KIA [9]. Sedangkan pada [10], [11], dan [12], aplikasi mobile pendukung KIA yang dikembangkan belum terintegrasi dengan sistem informasi berbasis web. Oleh karenanya, sebuah sistem informasi yang mengintegrasikan aplikasi berbasis web dan aplikasi mobile perlu 
INTENSIF, Vol.3 No.1 February 2019

ISSN: 2580-409X (Print) / 2549-6824 (Online)

Website: http://ojs.unpkediri.ac.id/index.php/intensif

dikembangkan untuk memenuhi kebutuhan tidak hanya bidan saja namun juga orang tua. Pada sistem informasi KIA bagi bidan (Si-Bidan) yang dikembangkan dalam penelitian ini mengintegrasikan sistem informasi berbasis web bagi bidan dan aplikasi mobile bagi orang tua. Aplikasi berbasis web dengan pengguna bidan berfungsi sebagai sarana pencatatan layanan, penyusunan laporan dan penyampaian informasi dari bidan. Sedangkan aplikasi mobile berbasis android dapat dimanfaatkan oleh orang tua untuk melihat informasi perkembangan kesehatan ibu dan anak serta informasi lain jadwal dan agenda yang disampaikan bidan.

\section{METODE PENELITIAN}

Pada bagian ini dijelaskan metode pengembangan perangkat lunak yang digunakan dalam pembangunan Si-Bidan dan model pengujian yang digunakan terhadap sistem informasi yang dikembangkan

\section{A. Metode Pengembangan Sistem}

Metode yang digunakan dalam pengembangan Si-Bidan adalah metode waterfall. Metode waterfall adalah metode dimana pengerjaan dari suatu sistem yang dilakukan secara berurutan dari analisis kebutuhan hingga implementasi sistem [13]. Jika langkah ke-1 belum dikerjakan, maka langkah ke-2 tidak dapat dikerjakan begitu seterusnya sebagaimana ditunjukan pada Gambar 1.

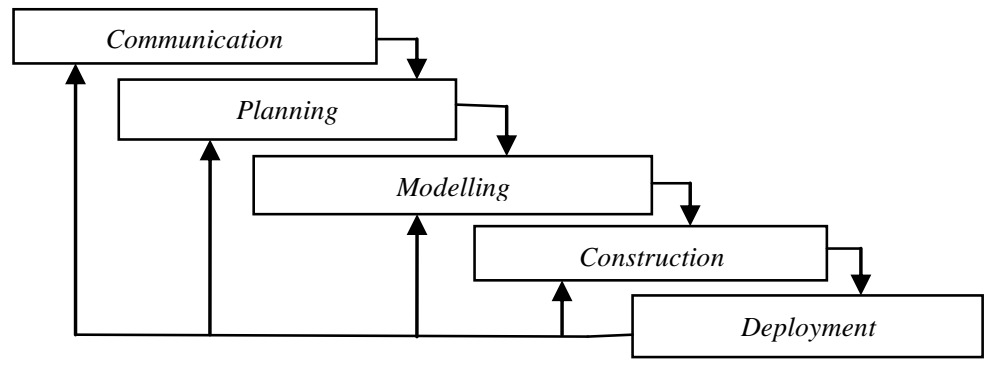

Gambar 1. DIAGRAM WATERFALL

Tahapan dalam pengembangan perangkat lunak menggunakan metode waterfall dapat dijelaskan sebagai berikut :

\section{Communication}

Pada tahapan ini dilakukan analisis kebutuhan perangkat lunak, dan pengumpulan data melalui tatap muka dengan customer. Pengumpulan data dilakukan melalui observasi fasilitas, observasi layanan, dan wawancara dengan bidan dan orangtua secara langsung mengenai proses bisnis dan kebutuhan pengguna akan sistem. Form-form dan buku catatan terkait pelayanan bidan dan dokumen laporan bidan juga dikumpulkan untuk keperluan analisa kebutuhan.

\section{Planning}

Data hasil pengamatan langsung, pengumpulan dokumen dan wawancara dengan bidan dan orang tua selanjutnya dianalisa. Dari hasil analisa diperolah kesimpulan bahwa diperlukan 
INTENSIF, Vol.3 No.1 February 2019

ISSN: 2580-409X (Print) / 2549-6824 (Online)

Website: http://ojs.unpkediri.ac.id/index.php/intensif

sebuah sistem informasi yang mampu memenuhi kebutuhan bidan dan orang tua. Sistem informasi ini terdiri dari aplikasi web untuk bidan yang terintegrasi dengan aplikasi mobile untuk orang tua.

\section{Modelling}

Pada tahap ini, disusun desain arsitektur sistem, use case diagram, activity diagram, dan rancangan basis data sistem. Antarmuka sistem juga dibuat baik untuk aplikasi berbasis web maupun aplikasi mobile. Desain antarmuka aplikasi web disesuaikan dengan form-form yang digunakan bidan dalam proses input data dan desain laporan sesuai dengan laporan kegiatan yang ada. Sedangkan antarmuka aplikasi mobile dibuat mengacu pada kebutuhan orang tua akan informasi kesehatan ibu dan anak.

\section{Construction}

Pada tahapan ini dibangun sistem informasi berbasis web menggunakan bahasa pemrograman PHP dengan framework codeigniter dan MySQL sebagai sistem manajemen basisdatanya. Sedangkan pada sisi mobile untuk pengguna ibu menggunakan android software development kit berbasis bahasa pemrograman Java. Sistem yang dikembangkan selanjutnya dilakukan uji fungsional menggunakan metode black-box testing. Pengujian dilakukan dengan melibatkan pengguna bidan dan orang tua. Hasil pengujian selanjutnya digunakan sebagai referensi perbaikan sistem.

\section{Deployment}

Sistem yang telah disempurnakan dan memenuhi kebutuhan fungsional pengguna bidan dan orang tua selanjutnya diimplementasikan untuk digunakan. Basis data sistem juga telah disinkronisasi sesuai dengan history data transaksi layana yang pernah diberikan oleh bidan sebelumnya.

\section{B. Pengujian Perangkat Lunak}

Pengujian dilakukan untuk memastikan apakah perangkat lunak atau sistem yang dibangun telah sesuai dengan kebutuhan pengguna yang sudah ditetapkan sebelumnya dalam software requirement. Dalam penelitian ini digunakan model pengujian black -box testing. Pengujian menitik beratkan pada pengujian fungsional sistem sehingga tidak mengharuskan penguji perangkat lunak memiliki pengetahuan tentang kode pemrograman dan implementasinya. Penguji akan berinteraksi melalui antarmuka yang disediakan sistem dengan memberikan masukan dan memeriksa keluarannya, juga menguji performa program atau menguji fungsifungsi yang tidak bekerja dengan benar [14]. Hasil pengujian ini selanjutnya akan menentukan apakah perangkat lunak dapat diterima customer ataukah perlu dilakukan perbaikan. 
INTENSIF, Vol.3 No.1 February 2019

ISSN: 2580-409X (Print) / 2549-6824 (Online)

Website: http://ojs.unpkediri.ac.id/index.php/intensif

\section{HASIL DAN PEMBAHASAN}

\section{A. Analisis Kebutuhan}

Gambaran sistem yang berjalan diperoleh dari hasil wawancara dengan bidan, pengamatan langsung aktifitas pelayanan bidan dan dokumen yang ada pada tempat praktek bidan. Gambaran tersebut menunjukkan secara garis besar kebutuhan akan sistem informasi ada pada dua pengguna yakni bidan dan ibu yang menjadi pasien bidan. Pengguna bidan membutuhkan komputerisasi pencatatan layanan KIA, pelaporan dan penyampaian informasi. Sedangkan pengguna ibu membutuhkan akses terhadap informasi kesehatan ibu dan anaknya.

\section{B. Rancangan Sistem}

Rancangan sistem terdiri dari rancangan arsitektur sistem, usecase diagram, dan rancangan basis data sistem.

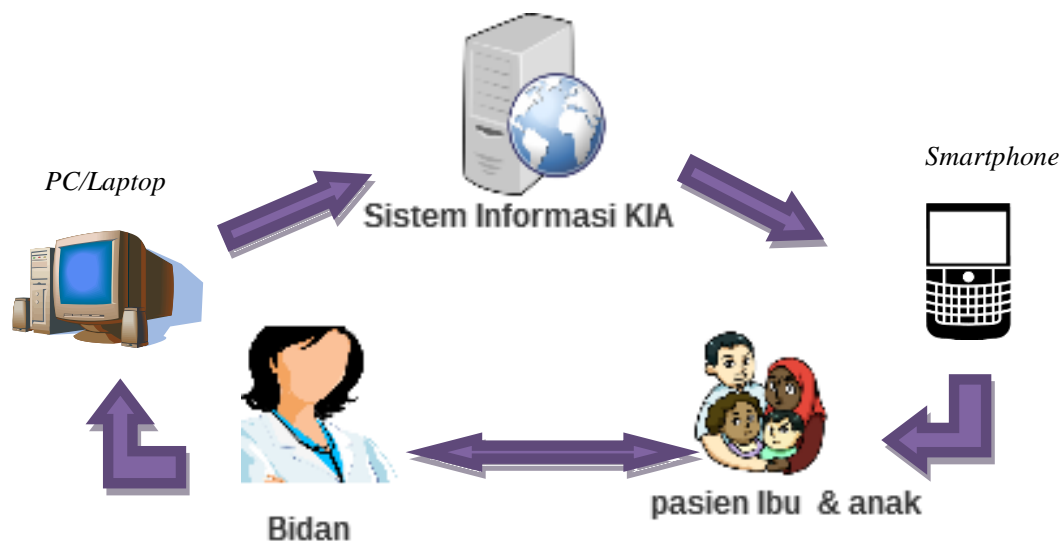

Gambar 2. RANCANGAN ARSITEKTUR SI-BIDAN

\section{Rancangan Arsitektur Sistem}

Si-Bidan pada gambar 2 dirancang untuk digunakan oleh dua pengguna utama yakni bidan dan ibu. Pengguna bidan berinteraksi dengan sistem melalui aplikasi berbasis web untuk mengelola pencatatan layanan KIA, penyampaian informasi dan pembuatan laporan kegiatan. Sedangkan pengguna ibu terhubung ke sistem melalui aplikasi android yang memanfaatkan jaringan internet untuk melihat catatan perkembangan anak dan kehamilannya. Untuk dapat memanfaatkan layanan sistem maka pengguna ibu harus melakukan registrasi terlebih dahulu. Proses registrasi ini ditangani langsung oleh bidan tempat ibu mendatangi posyandu.

\section{Usecase Diagram}

Usecase diagram bertujuan untuk mendefenisikan kebutuhan fungsional dari sistem yang akan dikembangkan [15]. Gambar 3 memperlihatkan usecase diagram Si-Bidan yang terbagi menjadi dua bagian utama yaitu sistem informasi berbasis web bagi pengguna bidan dan aplikasi 
INTENSIF, Vol.3 No.1 February 2019

ISSN: 2580-409X (Print) / 2549-6824 (Online)

Website: http://ojs.unpkediri.ac.id/index.php/intensif

berbasis android bagi pengguna ibu. Pada aplikasi berbasis web bidan dapat mengelola (create, read, update, dan delete) data pasien anak dan pasien ibu, mengelola catatan layanan kesehatan pasien anak dan ibu, mencetak laporan, dan mengelola pengumuman atau informasi yang akan disampaikan pada ibu. Bidan juga berlaku sebagai pengelola sistem yang memberikan hak akses pada pengguna ibu saat melakukan registrasi pengguna aplikasi android. Sedangkan pada sisi aplikasi android, pengguna ibu dapat melihat informasi atau pengumuman yang disampaikan oleh bidan dan melihat laporan kesehatan ibu dan anak.

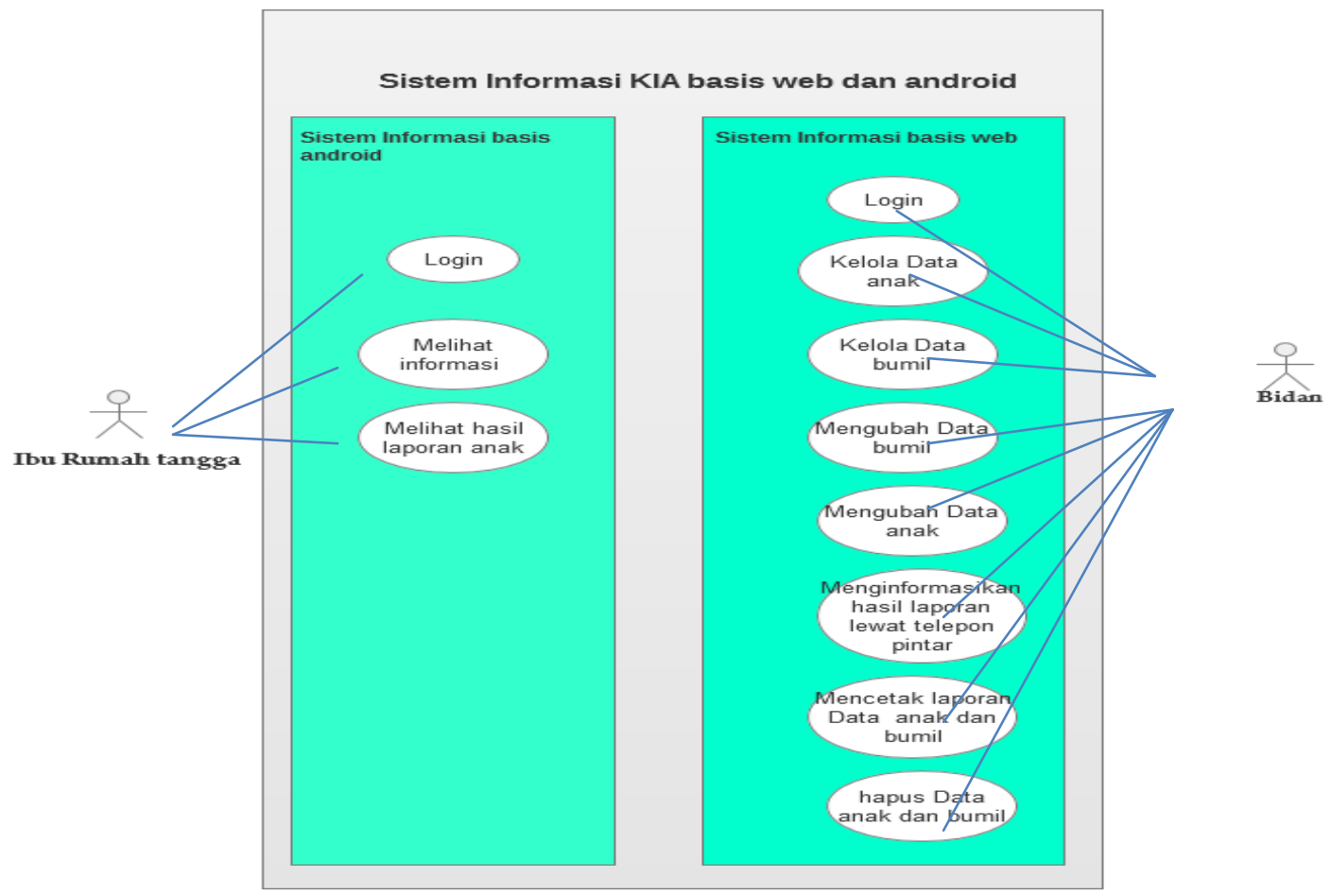

Gambar 3. USECASE DIAGRAM SI-BIDAN

\section{Rancangan Basisdata}

Rancangan basisdata Si-Bidan pada gambar 4 disajikan dalam bentuk entity relationship diagram (ERD). ERD berguna untuk menunjukan objek data dan hubungan - hubungan yang ada pada objek tersebut dengan menggunakan entity dan relationship [16]. Basisdata sistem berada pada server web yang dapat dikelola oleh bidan melalui antarmuka dan fungsi yang disediakan oleh sistem. 
INTENSIF, Vol.3 No.1 February 2019

ISSN: 2580-409X (Print) / 2549-6824 (Online)

Website: http://ojs.unpkediri.ac.id/index.php/intensif

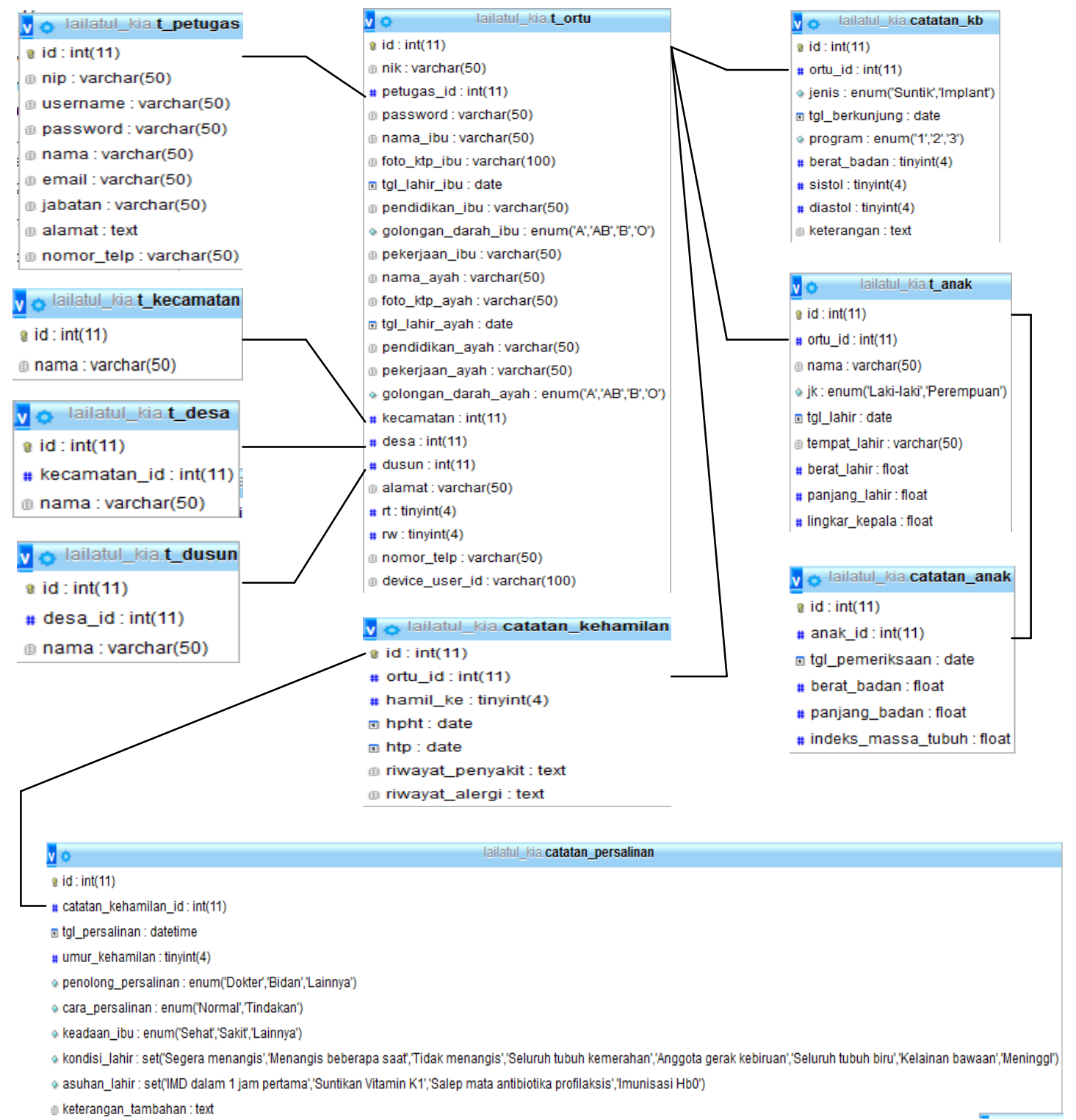

Gambar 4. ENTITY RELATIONSHIP DIAGRAM SI-BIDAN

\section{Implementasi}

Rancang Bangun Si-Bidan pada sisi web untuk pengguna bidan dikembangkan menggunakan bahasa pemrograman PHP dengan framework codeigniter dan MySQL sebagai sistem manajemen basisdatanya. Sedangkan pada sisi mobile untuk pengguna ibu menggunakan android software development kit berbasis bahasa pemrograman Java. 
INTENSIF, Vol.3 No.1 February 2019

ISSN: 2580-409X (Print) / 2549-6824 (Online)

Website: http://ojs.unpkediri.ac.id/index.php/intensif

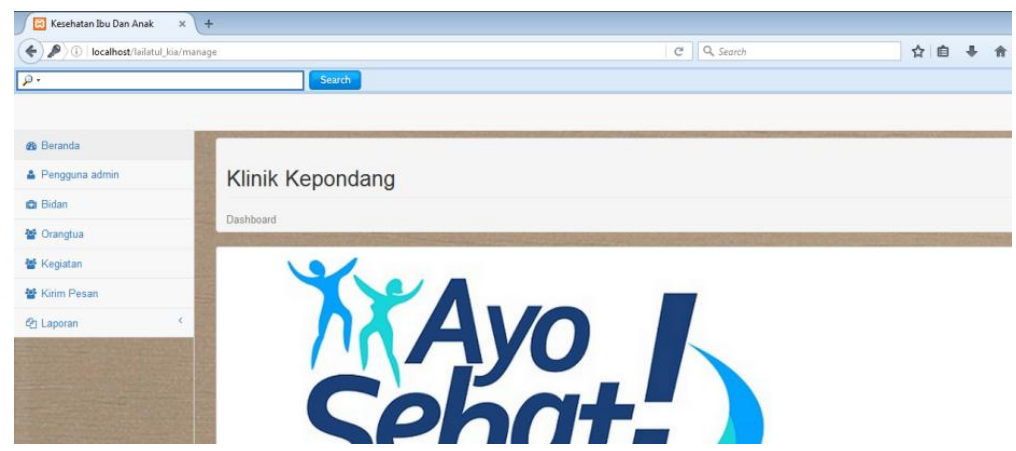

Gambar 5. TAMPILAN MENU WEB Si-BIDAN

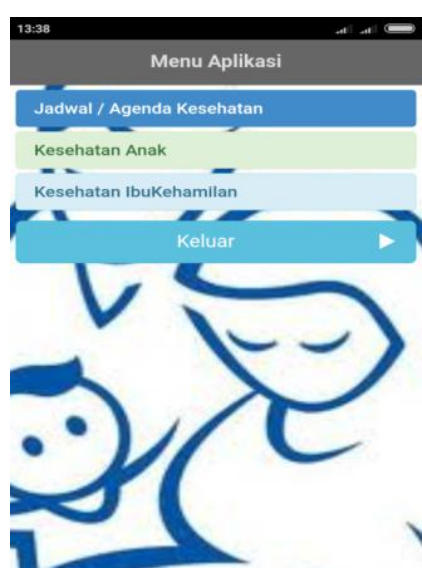

Gambar 6. TAMPILAN MENU ANDROID SI-BIDAN

Tabel 1 berisi penjelasan dari menu utama yang ada pada aplikasi web Si-Bidan yang ditunjukkan pada Gambar 5 dan Tabel 2 berisi penjelasan dari menu utama yang ada pada aplikasi android Si-Bidan yang ditunjukkan pada Gambar 6.

Tabel 1. MENU APLIKASI WEB SI-BIDAN

\begin{tabular}{lll}
\hline \hline No & Menu utama & Keterangan fungsional \\
\hline 1 & Beranda & Menampilkan halaman beranda \\
\hline 2 & Pengguna admin & Mengelola user admin (create, read, update, delete) \\
\hline 3 & Bidan & Mengelola user admin (create, read, update, delete) \\
\hline 4 & Orang tua & $\checkmark \quad \begin{array}{l}\text { Menu kelola pengguna berfungsi sebagai pengatur username, } \\
\text { password dan hak akses bagi pasien ibu / anak. }\end{array}$ \\
& $\checkmark \quad \begin{array}{l}\text { Mengelola data pasien ibu/anak. } \\
\text { Menu Cetak data berfungsi untuk mencetak data yang akan } \\
\end{array}$ & $\begin{array}{l}\text { Untuk mengelola informas kegiatan yang akan ditampilkan kepada } \\
\text { pengguna ibu di aplikasi android }\end{array}$ \\
\hline 5 & Kegiatan & Untuk mengirimkan pesan ke aplikasi android pengguna ibu \\
\hline 6 & Kirim Pesan & $\begin{array}{l}\text { Menampilkan keseluruhan data yang sudah diinputkan oleh bidan } \\
\text { dalam bentuk laporan berupa laporan status gizi anak, rekap persalinan, } \\
\text { rekap KB, dan grafik perkembangan anak }\end{array}$ \\
\hline 7 & Laporan &
\end{tabular}


INTENSIF, Vol.3 No.1 February 2019

ISSN: 2580-409X (Print) / 2549-6824 (Online)

Website: http://ojs.unpkediri.ac.id/index.php/intensif

Tabel 2. MENU APLIKASI ANDROID SI-BIDAN

\begin{tabular}{cll}
\hline \hline No & Menu utama & Keterangan fungsional \\
\hline 1 & $\begin{array}{l}\text { Jadwal / Agenda } \\
\text { Kesehatan }\end{array}$ & Melihat jadwal kegiatan yang diinformasikan oleh bidan \\
\hline 2 & Kesehatan Anak & $\begin{array}{l}\text { Melihat informasi tentang kesehatan anak pertama atau kedua yang } \\
\text { sudah melakukan pemeriksaan }\end{array}$ \\
\hline 3 & Kesehatan Ibu Hamil & $\begin{array}{l}\text { Melihat informasi tentang kesehatan ibu dan layanan KB yang telah } \\
\text { dilakukan }\end{array}$ \\
\hline
\end{tabular}

\section{Hasil Pengujian}

Pengujian black-box dilakukan untuk melihat keseuaian fungsionalitas sistem dengan kebutuhan pengguna. Pengujian ini melibatkan dua jenis pengguna sistem yakni bidan sebagai pengguna aplikasi web dan orang tua selaku pengguna aplikasi mobile. Hasil pengujian terhadap aplikasi android pada Tabel 3 dan aplikasi web pada Tabel 4 menunjukkan bahwa sistem yang dibangun telah sesuai dengan kebutuhan fungsional yang diharapkan.

Tabel 3. HASIL PENGUJIAN BLACK-BOX APLIKASI MOBILE SI-BIDAN

\begin{tabular}{|c|c|c|c|c|}
\hline Kasus Uji & Langkah Penelitian & Hasil yang diharapkan & Hasil Uji & 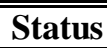 \\
\hline $\begin{array}{l}\text { Halaman } \\
\text { Login. }\end{array}$ & $\begin{array}{l}\text { Memasukkan Username } \\
\text { dan Password yang sudah } \\
\text { terdaftar. }\end{array}$ & $\begin{array}{l}\text { Menampilkan halaman } \\
\text { menu. }\end{array}$ & $\begin{array}{l}\text { Tampilan } \\
\text { halaman menu. }\end{array}$ & Sesuai. \\
\hline Lihat Menu & $\begin{array}{l}\text { Pilih menu, dan klik pada } \\
\text { setiap submenu yang } \\
\text { diinginkan. }\end{array}$ & $\begin{array}{l}\text { Menampilkan } \\
\text { dengan pilihan mesuai } \\
\text { yang dipilih. }\end{array}$ & $\begin{array}{l}\text { Tampilan } \\
\text { submenu sesuai } \\
\text { yang dipilih }\end{array}$ & Sesuai. \\
\hline
\end{tabular}

Tabel 4. HASIL PENGUJIAN BLACK-BOX APLIKASI WEB SI-BIDAN

\begin{tabular}{|c|c|c|c|c|}
\hline Kasus Uji & Langkah Penelitian & Hasil yang diharapkan & Hasil Uji & Status \\
\hline $\begin{array}{l}\text { Halaman } \\
\text { Login. }\end{array}$ & $\begin{array}{l}\text { Memasukkan Username } \\
\text { dan Password yang sudah } \\
\text { terdaftar berupa nama dan } \\
\text { NIK dari pengguna. }\end{array}$ & $\begin{array}{l}\text { Menampilkan halaman } \\
\text { utama. }\end{array}$ & $\begin{array}{l}\text { Tampilan } \\
\text { halaman utama. }\end{array}$ & Sesuai. \\
\hline $\begin{array}{l}\text { Menu Orang } \\
\text { tua }\end{array}$ & $\begin{array}{l}\text { Masuk menu Orang tua, } \\
\text { menginputkan data orang } \\
\text { tua. }\end{array}$ & $\begin{array}{l}\text { Menampilkan data orang } \\
\text { tuayang sudah ada } \\
\text { dikelola oleh bidan. }\end{array}$ & $\begin{array}{l}\text { Tampilan data } \\
\text { orang tua. }\end{array}$ & Sesuai. \\
\hline $\begin{array}{c}\text { Menu } \\
\text { Persalinan. }\end{array}$ & $\begin{array}{lr}\text { Masuk menu persalinan, } \\
\text { menginputkan } \\
\text { persalinan. }\end{array}$ & $\begin{array}{lr}\text { Menampilkan data } \\
\text { persalinan ibu yang } \\
\text { melakukan proses } \\
\text { persalinan di bidan. }\end{array}$ & $\begin{array}{lr}\text { Tampilan data } \\
\text { persalinan yang } \\
\text { sudah di data } \\
\text { oleh bidan. }\end{array}$ & Sesuai. \\
\hline $\begin{array}{l}\text { Menu Data } \\
\text { anak. }\end{array}$ & $\begin{array}{l}\text { Masuk menu Data anak, } \\
\text { mengelola data anak. }\end{array}$ & $\begin{array}{l}\text { Menampilkan data } \\
\text { anakyang sudah ada } \\
\text { dikelola oleh bidan. }\end{array}$ & $\begin{array}{l}\text { Tampilan data } \\
\text { anak. }\end{array}$ & Sesuai. \\
\hline $\begin{array}{l}\text { Menu Data } \\
\text { KB. }\end{array}$ & $\begin{array}{l}\text { Masuk Menu Data KB, } \\
\text { mengelola data KB. }\end{array}$ & $\begin{array}{l}\text { Menampilkan data KB } \\
\text { ibu yang melakukan } \\
\text { proses KB di bidan. }\end{array}$ & $\begin{array}{lr}\text { Tampilan } & \text { data } \\
\text { KB yang } & \text { sudah } \\
\text { di data oleh } \\
\text { bidan. }\end{array}$ & Sesuai. \\
\hline Menu Laporan & $\begin{array}{l}\text { Masuk Menu Laporan } \\
\text { Keseluruhan }\end{array}$ & $\begin{array}{l}\text { Menampilkan } \\
\text { keseluruhan } \\
\text { rekap gizil } \\
\text { persalinan, dan juga KB. }\end{array}$ & $\begin{array}{l}\text { Tampilan hasil } \\
\text { laporan gizi } \\
\text { anak, persalinan } \\
\text { dan juga laporan } \\
\text { rekap KB. }\end{array}$ & Sesuai. \\
\hline
\end{tabular}


INTENSIF, Vol.3 No.1 February 2019

ISSN: 2580-409X (Print) / 2549-6824 (Online)

Website: http://ojs.unpkediri.ac.id/index.php/intensif

\section{KESIMPULAN DAN SARAN}

Pada Penelitian ini telah dikembangkan sistem informasi kesehatan ibu dan anak yang mengintegrasikan aplikasi web untuk bidan dan aplikasi mobile untuk orang tua. Aplikasi web memfasilitasi bidan untuk melakukan pencatatan layanan, penyusunan laporan dan penyampaian informasi. Sedangkan aplikas mobile memungkinkan orang tua untuk secara langsung memantau perkembangan informasi kesehatan ibu dan anak. Hasil pengujian menggunakan metode blackbox terhadap sistem ini menunjukkan bahwa sistem telah mampu memenuhi kebutuhan pengguna bidan dan ibu. Pengembangan sistem selanjutnya dapat dilakukan dengan menambahkan fitur konsultasi baik chat secara langsung maupun dalam bentuk forum tanya jawab, notifikasi pengingat jadwal, dan pendaftaran antrian melalui smartphone.

\section{UCAPAN TERIMAKASIH}

Penulis mengucapkan terima kasih kepada Direktorat Riset dan Pengabdian Masyarakat (DRPM) Kemenristekditi yang telah memberi dukungan finansial terhadap penelitian ini melalui skema penelitian dosen pemula(PDP).

\section{DAFTAR PUSTAKA}

[1] Y. P. Sumihar and C. P. Wijaya, "Membangun Aplikasi Menggunakan Framework Kohana ( Studi Kasus Puskesmas Kalasan ),” Maj. Ilm., vol. 08, no. 01, pp. 44-54, 2016.

[2] A. E. Prasetyawati, Kesehatan Ibu dan Anak (KIA). Yogyakarta: Nuha Medika, 2012.

[3] W. Utami and A. A. Bachri, "Pengaruh Dimensi Kualitas Pelayanan Puskesmas S . Parman Banjarmasin Terhadap Kepuasan Pasien Dalam Memperoleh Pelayanan Kesehatan," J. Wawasan Manaj., vol. 1, no. 1, pp. 65-90, 2013.

[4] J. R. Shah, M. B. Murtaza, and E. Opara, "Electronic Health Records: Challenges and Opportunities," vol. 23, no. 3, pp. 189-204, 2014.

[5] A. Faried et al., "Mother and children health reporting system: Innovative information system application in the rural West Bandung Area, Indonesia, by using multimodal communications systems," in Proceedings - 2015 4th International Conference on Instrumentation, Communications, Information Technology and Biomedical Engineering, ICICI-BME 2015, 2016.

[6] M. Manoj, "Customising DHIS2 for Maternal and Child Health Information Management in Sri Lanka," Sri Lanka J. Bio-Medical Informatics, 2013.

[7] L. Ambarwati and W. Wikusna, "Aplikasi Pelayanan Kesehatan Ibu dan Anak ( KIA ) di Puskesmas Cinunuk," J. Teknol. Inf., vol. 2, no. 3, pp. 92-96, 2015.

[8] D. L. Fithri, "Aplikasi Manajemen Posyandu untuk Peningkatan Kesehatan Ibu dan Anak," J. SITECH, vol. 1, no. 1, pp. 41-48, 2018.

[9] L. Annisa, "Pengembangan sistem informasi," Universitas Gadjah Mada, 2016.

[10] E. R. Mangone, V. Lebrun, and K. E. Muessig, "Mobile Phone Apps for the Prevention of Unintended Pregnancy: A Systematic Review and Content Analysis," JMIR mHealth uHealth, 2016.

[11] Agustian, Nurhadi, and Irawan, "Perancangan Aplikasi Kesehatan Ibu Dan Anak( KIA ) 
INTENSIF, Vol.3 No.1 February 2019

ISSN: 2580-409X (Print) / 2549-6824 (Online)

Website: http://ojs.unpkediri.ac.id/index.php/intensif

Berbasis Android," J. Ilm. Media Process., vol. 10, no. 2, pp. 570-581, 2015.

[12] A. GhanyIsmaeel and E. Khadhm Jabar, "Effective System for Pregnant Women using Mobile GIS," Int. J. Comput. Appl., 2013.

[13] R. S. Pressman, Software Engineering A Practioner's Approach. 2010.

[14] S. Nidhra, "Black Box and White Box Testing Techniques - A Literature Review," Int. J. Embed. Syst. Appl., 2012.

[15] Rosa A.S and M. Shalahuddin, "Use Case Diagram," Rekayasa Perangkat Lunak, 2014.

[16] H. K. Al-Masree, "Extracting Entity Relationship Diagram (ERD) From Relational Database Schem," Int. J. Database Theory Appl., 2015. 